\title{
Pengukuran Kepuasan dan Loyalitas Konsumen terhadap Kualitas Layanan Taksi Resmi Bandar Udara Juanda Surabaya
}

\author{
Azizah Yulia Safitri, Berto Mulia Wibawa, dan Dewie Saktia Ardiantono \\ Departemen Manajemen Bisnis, Fakultas Bisnis dan Manajemen Teknologi, \\ Institut Teknologi Sepuluh Nopember (ITS) \\ e-mail: azizahsafitri02@yahoo.com
}

\begin{abstract}
Abstrak-Taksi resmi Bandar Udara Juanda Surabaya yang dikelola oleh PT Angkasa Pura I (Persero) mengalami penurunan pendapatan dari tahun ke tahun yang mengakibatkan revenue share kepada PT Angkasa Pura I (Persero) kurang maksimal. Penelitian ini dilakukan dengan tujuan untuk menganalisis kepuasan dan loyalitas konsumen terhadap kualitas layanan taksi resmi Bandar Udara Juanda Surabaya berdasarkan persepsi dan ekspektasi yang mereka miliki, sehingga dapat direkomendasikan perbaikan terhadap atribut kualitas layanan yang dianggap kurang memuaskan. Metode yang digunakan American Customer Satisfaction Index (ACSI) dan Customer Loyalty Index (CLI). Hasil penelitian menunjukkan bahwa konsumen merasa cukup puas dan cukup loyal terhadap layanan taksi resmi Bandar Udara Juanda Surabaya akan tetapi masih merasa terdapat beberapa atribut layanan taksi resmi Bandar Udara Juanda Surabaya yang masih memiliki kinerja jauh dari harapan yang mereka miliki. Terdapat beberapa implikasi manajerial yang dapat dipertimbangkan untuk digunakan oleh operator taksi resmi Bandar Udara Juanda Surabaya dan PT Angkasa Pura I (Persero) dengan tujuan meningkatkan kualitas layanan sehingga tercipta kepuasan dan loyalitas yang maksimal. Implikasi manajerial tersebut diantaranya mengubah sistem penetapan tarif taksi menjadi argo meter, mengubah cara penawaran jasa taksi kepada pengunjung Bandar Udara Juanda Surabaya menjadi lebih memanfaatkan media online, dan pengadaan speed monitoring system untuk meningkatkan keamanan didalam kendaraan.
\end{abstract}

Kata Kunci- ACSI, CLI, Ekspektasi, Kepuasan, Loyalitas, Persepsi

\section{PENDAHULUAN}

$\mathrm{S}$ EKTOR transportasi merupakan salah satu bisnis yang saat ini sedang semakin berkembang secara pesat dan kompetitif. Tingginya mobilitas penduduk saat ini mengakibatkan kebutuhan akan transportasi di kalangan masyarakat meningkat dan kemajuan teknologi berkembang semakin pesat sehingga mampu mendorong transformasi dan inovasi dalam bisnis transportasi terutama pada transportasi konvensional dan online ride sharing (transportasi berbasis aplikasi online). Transportasi konvensional adalah sebuah layanan transportasi bersama yang tersedia untuk digunakan oleh masyarakat umum seperti bus kota, angkutan umum, taksi, dan lainnya. Ketika konsumen ingin menggunakannya maka mereka diharuskan untuk mendatangi tempat-tempat yang disediakan sebagai pangkalan seperti pul taksi, terminal, dan lainnya. Sedangkan transportasi berbasis aplikasi online merupakan suatu platform transportasi dimana pelanggan dan penyedia layanan berinteraksi dalam peerto-peer marketplace yang difasilitasi oleh Internet [1].

Kehadiran transportasi berbasis aplikasi online saat ini memang mampu menjadi solusi di tengah-tengah masyarakat. Perkembangan transportasi berbasis aplikasi online pun berkembang pesat namun kenyataannya menggeser posisi transportasi konvensional salah satunya adalah taksi resmi Bandar Udara Juanda Surabaya. Taksi resmi Bandar Udara Juanda Surabaya merupakan salah satu fasilitas land transport yang disediakan oleh PT Angkasa Pura I guna mendukung kebutuhan pengunjung bandara Juanda Surabaya.

Revenue share yang diterima oleh PT Angkasa Pura mengalami penurunan dari tahun 2016 hingga 2017 dikarenakan pendapatan taksi resmi Bandar Udara Juanda Surabaya yang juga mengalami penurunan. Terjadinya penurunan pendapatan taksi resmi Bandar Udara Juanda Surabaya tersebut disebabkan oleh perilaku konsumen yang beralih menggunakan transportasi berbasis aplikasi online. Terdapat beberapa kemungkinan yang terjadi apabila pelanggan memutuskan untuk berhenti menggunakan produk atau jasa, diantaranya adalah pelanggan sudah merasa cukup atas produk atau jasa yang dipakai, dan yang kedua adalah pelanggan melihat produk subtitusi lain yang lebih baik dan mampu memberikan tingkat kepuasan yang lebih dari produk yang sebelumnya [2].

Banyak faktor yang memengaruhi kepuasan pelanggan, salah satunya adalah harga. Keberadaan pesaing yang menawarkan harga lebih terjangkau dan memberlakukan harga promo dapat menyebabkan menurunnya tingkat kepuasan pelanggan dan membuat mereka enggan menggunakan kembali layanan tersebut [3]. Kedua, sebagai bisnis yang bergerak di bidang jasa, kualitas layanan merupakan komponen paling utama yang harus diperhatikan oleh Perusahaan. Kualitas layanan yang buruk dalam sektor transportasi dapat menciptakan ketidakpuasan dan mengarahkan pelanggan untuk beralih menuju ke pesaing [4]. Dari perspektif pemasaran, kualitas layanan yang lebih baik, kepuasan pelanggan serta tingkat loyalitas yang lebih tinggi akan mempertahankan posisi kompetitif suatu perusahaan di tengah ketatnya persaingan dan meningkatkan profitabilitas di bawah persaingan yang ketat [5]. Kualitas layanan merupakan salah satu konsep layanan perusahaan yang bisa diandalkan untuk bertahan di tengah persaingan yang semakin ketat [6]. Kualitas layanan dapat diukur dan diketahui dengan cara membandingkan persepsi konsumen atas pelayanan yang mereka terima dan rasakan dengan ekspektasi dari layanan yang mereka inginkan [7].

Semua studi sebelumnya mengidentifikasi persepsi pengguna sebagai alat penting untuk mengukur kualitas layanan. Sebagian besar studi sebelumnya memberikan ukuran yang baik dari kualitas layanan yang ada tetapi sangat sedikit studi memberikan ukuran kualitas layanan yang diharapkan atau diinginkan oleh konsumen. Harapan konsumen terhadap kualitas layanan sangatlah bervariasi sehingga sangat penting untuk mengetahui harapan 
konsumen terkait kualitas layanan selain persepsi yang dirasakan. Melihat permasalahan yang sedang terjadi tersebut, maka penelitian mengenai pengukuran kepuasan dan loyalitas konsumen terhadap kualitas layanan taksi resmi Bandar Udara Juanda Surabaya ini menjadi penting dan dianggap perlu untuk dilakukan, agar dapat mengetahui tingkat kepentingan masing-masing atribut kualitas layanan untuk dilakukan perbaikan, tingkat kepuasan, dan tingkat loyalitas konsumen. Hasil penelitian tersebut diharapkan nantinya akan membantu dalam memberikan rekomendasi alternatif bagi operator taksi resmi Bandar Udara Juanda Surabaya dan PT Angkasa Pura I (Persero) untuk meningkatkan kualitas layanan dari taksi resmi Bandar Udara Juanda Surabaya sehingga terjadi peningkatan pendapatan taksi resmi Bandar Udara Juanda Surabaya pula.

\section{II.LANDASAN TEORI}

\section{A. Persepsi}

Persepsi mencerminkan sikap orang yang merupakan konsep psikologis abstrak dan memainkan peran penting dalam mengatur perilaku. Pengukuran persepsi mewujudkan kesenjangan antara harapan dan realita yang dirasakan oleh penumpang [7].

\section{B. Ekspektasi}

Ekspektasi atau harapan merupakan segala sesuatu yang diyakini oleh konsumen tentang apa yang akan didapatkannya terkait dengan suatu kinerja produk atau pelayanan tertentu [8]. Ekspektasi didefinisikan sebagai keinginan konsumen yang mereka rasa harus ditawarkan oleh penyedia layanan [9]

\section{C.Dimensi Kualitas Layanan}

Kualitas jasa yang dirasakan oleh konsumen adalah hasil dari proses evaluasi konsumen dengan cara membandingkan persepsi yang mereka rasakan tentang penyampaian jasa dan hasilnya terhadap apa yang mereka harapkan [10]. Terdapat empat dimensi kualitas layanan yang digunakan dalam penelitian ini yang di adopsi dari Deb dan Ahmed (2018) yaitu sebagai berikut:

1. Safety (Keamanan)

Keamanan mengacu pada kemungkinan terlibat dalam kecelakaan di jalan keamanan atau bahkan kemungkinan menjadi korban kejahatan [11]. Berdasarkan hal tersebut, Deb dan Ahmed (2018) merumuskan beberapa indikator terkait dimensi safety yaitu (1) Boarding and alighting time; (2) On board safety against crime; (3) Safety in terms of accidents; dan (4) Safety in the bus stops.

\section{Comfort (Kenyamanan)}

Menurut Dell'Olio et al (2011), Meningkatkan kenyamanan penumpang selama perjalanan dapat dilakukan dengan cara menjaga kendaraan dalam kondisi sempurna, membersihkannya secara teratur dan menjaga kondisi baik mereka saat ini, menyediakan kursus untuk pengemudi dengan pengendaraan yang tenang sehingga meningkatkan persepsi keselamatan selama perjalanan, menyediakan ventilasi konstan yang baik dan suhu yang menyenangkan di dalam transportasi selama perjalanan. Berdasarkan hal tersebut, Deb dan Ahmed (2018) merumuskan beberapa indikator terkait dimensi comfort yaitu (1) condition of vehicle; (2) cleanliness of the vehicle; (3) cleanliness of the seats; (4) condition of the doors and windows; (5) comfortability of the seats; (6) availability of the seats; (7) overcrowding nature; (8) behavior of staffs;
(9) overall journey experience; (8) facilities provided for the disabled; (9) frequency of the breakdowns.

\section{Accessibility (Aksesibilitas)}

Aksesibilitas mengacu pada kemampuan orang untuk mencapai barang, layanan, dan aktivitas, yang merupakan tujuan akhir dari sebagian besar aktivitas transportasi. Banyak faktor yang memengaruhi aksesibilitas, termasuk mobilitas, kualitas dan keterjangkauan opsi transportasi, konektivitas sistem transportasi, pengganti mobilitas, dan pola penggunaan lahan [13]. Berdasarkan hal tersebut, Deb dan Ahmed (2018) merumuskan beberapa indikator terkait dimensi Accessibility yaitu (1) availability of the service; (2) prior information about the bus fare; (3) travel cost; (4) travel speed; dan (5) regularity of the service.

\section{Timely Performances (Kinerja Waktu)}

Menurut Van Oort (2011), Timely performances apabila diukur dari perspektif penumpang termasuk waktu tunggu penumpang dan waktu perjalanan. Aspek terkait waktu perjalanan penumpang adalah termasuk rata-rata waktu tunggu, waktu tunggu tambahan, waktu perjalanan dan waktu perjalanan tambahan [15]. Berdasarkan hal tersebut, Deb dan Ahmed (2018) merumuskan beberapa indikator terkait dimensi timely performances yaitu (1) arrival and departure time; (2) prior information about the journey time; dan (3) prior information about the waiting time.

\section{D.Kepuasan Pelanggan}

Kepuasan mengacu pada perasaan senang atau kecewa seseorang yang dihasilkan dari membandingkan kinerja produk dalam kaitannya dengan harapannya [5]. Sedangkan menurut Lovelock dan Wirtz (2011), Kepuasan merupakan sebuah penilaian seperti sikap setelah pengalaman konsumsi.

Tabel 1.

Dimensi Loyalitas Pelanggan

\begin{tabular}{cl}
\hline \hline $\begin{array}{c}\text { Variabel } \\
\text { Indikator }\end{array}$ & \multicolumn{1}{c}{ Definisi } \\
\hline L1 & Merekomendasikan layanan kepada orang yang meminta \\
L2 & saran \\
L3 & Berbicara maupun berkomentar positif mengenai layanan \\
L4 & Menggunakan layanan secara terus menerus \\
\hline \hline
\end{tabular}

\section{E. Loyalitas Pelanggan}

Loyalitas merupakan suatu kesediaan konsumen untuk melanjutkan pembelian pada sebuah perusahaan dalam jangka waktu yang panjang dan mempergunakan produk atau jasa secara berulang, serta merekomendasikannya kepada teman-teman dan perusahaan lain secara sukarela [16]. Menurut Griffin (2010), Loyalitas pelanggan cenderung lebih dekat dengan perilaku (behavior) bukan sikap (attitude).

\section{METODE PENELITIAN}

\section{A. Desain Penelitian}

Jenis penelitian ini adalah penelitian deskriptif dengan pendekatan kuantitatif untuk mengetahui tingkat kepuasan dan loyalitas pengguna taksi resmi Bandar Udara Juanda Surabaya.

\section{B. Sampel dan Metode Pengumpulan Data}

Teknik pengumpulan data yang digunakan adalah nonprobability sampling dengan teknik convenience sampling. Jumlah sampel pada penelitian ini sebanyak 214 responden dengan kriteria pengguna taksi resmi Bandar Udara Juanda Surabaya dalam tiga bulan terakhir. Untuk melakukan 
pengukuran persepsi dan ekspektasi konsumen pada pernyataan kuesioner maka digunakan skala likert 7 poin.

Tabel 2.

Rentang skala CSI

\begin{tabular}{ccc}
\hline \hline Rentang Skala & Persentase & Interpretasi \\
\hline $0.81-1.00$ & $81-100 \%$ & Sangat Puas \\
$0.61-0.80$ & $61-80 \%$ & Puas \\
$0.41-0.60$ & $41-60 \%$ & Cukup Puas \\
$0.21-0.40$ & $21-40 \%$ & Tidak Puas \\
$0.00-0.20$ & $0-20 \%$ & Sangat Tidak Puas \\
\hline \hline
\end{tabular}

Tabel 3.

Definisi Operasional Variabel

\begin{tabular}{|c|c|c|}
\hline Variabel & Variabel Indikator & Definisi \\
\hline \multirow{2}{*}{ Safety } & S1 & $\begin{array}{l}\text { Keamanan terhindar dari tindakan } \\
\text { kriminal saat menggunakan layanan }\end{array}$ \\
\hline & S2 & $\begin{array}{l}\text { Keamanan terhindar dari kecelakaan } \\
\text { saat menggunakan layanan }\end{array}$ \\
\hline \multirow{10}{*}{ Comfort } & $\mathrm{C} 1$ & Kondisi fisik kendaraan \\
\hline & $\mathrm{C} 2$ & Kebersihan kendaraan \\
\hline & $\mathrm{C} 3$ & Kebersihan tempat duduk kendaraan \\
\hline & $\mathrm{C} 4$ & Kondisi pintu dan jendela kendaraan \\
\hline & $\mathrm{C} 5$ & $\begin{array}{l}\text { Kenyamanan tempat duduk } \\
\text { kendaraan }\end{array}$ \\
\hline & C6 & $\begin{array}{l}\text { Kepadatan wilayah sebagai lokasi } \\
\text { penawaran layanan }\end{array}$ \\
\hline & $\mathrm{C} 7$ & Sikap pengemudi kendaraan \\
\hline & C8 & $\begin{array}{l}\text { Pengalaman secara keseluruhan saat } \\
\text { menggunakan layanan }\end{array}$ \\
\hline & C9 & Kondisi mesin kendaraan \\
\hline & $\mathrm{C} 10$ & Penampilan pengemudi kendaraan \\
\hline \multirow{4}{*}{ Accessibility } & A1 & $\begin{array}{l}\text { Kemudahan menjangkau lokasi } \\
\text { penjemputan }\end{array}$ \\
\hline & A2 & $\begin{array}{l}\text { Kemudahan memeroleh informasi } \\
\text { tarif layanan }\end{array}$ \\
\hline & A3 & Keterjangkauan tarif layanan \\
\hline & A4 & $\begin{array}{l}\text { Ketepatan pengemudi kendaraan } \\
\text { dalam mengatur kecepatan untuk } \\
\text { sampai ke tempat tujuan }\end{array}$ \\
\hline \multirow{4}{*}{$\begin{array}{c}\text { Timely } \\
\text { Performance } \\
\text { s }\end{array}$} & $\mathrm{T} 1$ & $\begin{array}{l}\text { Kemudahan memeroleh informasi } \\
\text { waktu penjemputan dan } \\
\text { keberangkatan }\end{array}$ \\
\hline & & Kemudahan memeroleh informasi \\
\hline & $\mathrm{T} 2$ & $\begin{array}{l}\text { waktu yang akan di tempuh selama } \\
\text { perjalanan }\end{array}$ \\
\hline & T3 & $\begin{array}{l}\text { Kemudahan memeroleh informasi } \\
\text { waktu tunggu }\end{array}$ \\
\hline
\end{tabular}

\section{Metode Analisis Data}

Berikut adalah metode analisis data pada penelitian ini:

1. American Customer Satisfaction Index (ACSI)

Penelitian ini menggunakan analisis American Customer Satisfaction Index (ACSI) yaitu model indeks kepuasan pelanggan yang memiliki validitas prediktif lebih besar dibandingkan kebanyakan ukuran kepuasan pelanggan lainnya [18]. Nilai ACSI diperoleh melalui penilaian terhadap kinerja, harapan, dan kepuasan pelanggan. Skor kepuasan pelanggan ACSI adalah rata-rata tertimbang dari jawaban masing-masing tiga pertanyaan tersebut, menggunakan bobot kepemilikan yang berbeda untuk industri yang berbeda. Berikut ini adalah rumus yang digunakan dalam mengukur tingkat kepuasan pelanggan menggunakan ACSI [19].

$(($ Kepuasan-1 $) * .3885+($ Expectancy-1 $) * .3190+($ Kinerja-1 $) * .2925) / 9 * 100$

Langkah pertama yang dilakukan dalam menghitung nilai ACSI adalah melakukan penilaian terhadap expentancy (harapan), kinerja, dan kepuasan pelanggan. Kemudian dari masing-masing indikator tersebut akan dicari rata-rata tertimbangnya dan dihitung menggunakan bobot yang telah ditetapkan oleh perhitungan ACSI. Setelah diketahui nilai dari ACSI, maka kemudian nilai tersebut dicocokan dengan rentang skala CSI yang telah ditetapkan [20].

\section{Customer Loyalty Index (CLI)}

Customer Loyalty Index (CLI) merupakan metode penelitian untuk mengetahui seberapa besar tingkat loyalitas pelanggan suatu produk atau jasa. Menurut Wibowo et al (2018) rumus untuk memeroleh nilai CLI adalah sebagai berikut:

$$
C L I=\frac{\sum_{i}^{n} 1 \text { (willing statement) } \times 100 \%}{N}
$$

Setelah dilakukan perhitungan CLI maka akan didapatkan hasil tingkat loyalitas pelanggan. Rentang skala hasil Customer loyalty index disajikan pada Tabel 5 berikut.

Tabel 4. Rentang Skala CLI

\begin{tabular}{ccc}
\hline \hline Indikator Loyalitas & Willing Statement & CLI (\%) \\
\hline L1 & 3,86 & 55,21 \\
L2 & 3,65 & 52,07 \\
L3 & 4,11 & 58,75 \\
L4 & 3,13 & 44,66 \\
& & 52,67 \\
\hline \hline
\end{tabular}

\section{ANALISIS DAN DISKUSI}

\section{A. Deskripsi Hasil Penelitian}

Dari 214 responden penelitian, terdapat 103 laki-laki dan 111 perempuan yang mengisi kuesioner yang didominasi oleh orang berusia 21 hingga 30 tahun yaitu sebanyak 108 orang dan berusia 41 hingga 50 tahun sebanyak 42 orang. Mayoritas dari responden penelitian adalah orang yang sudah bekerja dan memiliki tingkat pendidikan terakhir sarjana dengan rata-rata penghasilan per bulan lebih dari Rp.3.000.000. Jenis kepentingan yang paling banyak dimiliki oleh responden penelitian untuk menggunakan taksi resmi Bandar Udara Juanda Surabaya adalah pulang ke rumah dan pekerjaan dengan biaya yang sering dikeluarkan adalah kurang dari $\leq \mathrm{Rp} 150.000$. Sedangkan untuk jenis taksi yang sering digunakan adalah taksi prima juanda dan blue bird dengan alasan sering menggunakan adalah adanya keterbatasan pilihan penyedia taksi.

\section{B. Deskripsi Data}

Pengguna taksi resmi Bandar Udara Juanda Surabaya menaruh harapan yang sangat tinggi terhadap keamanan dalam menggunakan taksi resmi Bandar Udara Juanda Surabaya dengan nilai rata-rata jawaban sebesar 6,70 . Mereka menaruh harapan yang sangat tinggi baik pada keamanan terhindar dari kriminal maupun kecelakaan dengan melihat angka modus dari masing-masing atribut sebesar 7. Nilai persepsi dan kepuasan pengguna taksi resmi Bandar Udara Juanda Surabaya terendah terletak pada kenyamanan menggunakan layanan yaitu pada atribut ketidakpadatan terminal kedatangan sebagai lokasi penawaran jasa dan kemudahan menggunakan layanan yaitu pada atribut keterjangkauan tarif taksi.

Mayoritas pengguna taksi resmi Bandar Udara Juanda Surabaya merasa netral bahwa keputusan menggunakan taksi resmi Bandar Udara Juanda Surabaya adalah keputusan yang benar dan bijaksana. Walaupun begitu, mereka merasa agak tidak setuju bahwa mereka merasa secara keseluruhan puas atas layanan taksi resmi Bandar Udara Juanda Surabaya melihat jawaban responden yang paling banyak adalah angka 3 . Kondisi saat ini juga menunjukkan bahwa pengguna taksi resmi Bandar Udara Juanda Surabaya merasa netral bahwa mereka akan 
merekomendasikan taksi resmi Bandar Udara Juanda Surabaya kepada orang lain yang meminta saran dan menggunakan layanan di lain kesempatan. Namun di sisi lain, mayoritas dari mereka merasa agak tidak setuju untuk menyampaikan hal-hal positif terkait layanan taksi resmi Bandar Udara Juanda Surabaya dan merasa tidak setuju untuk menggunakan taksi resmi Bandar Udara Juanda Surabaya secara terus menerus.

\section{Analisis American Customer Satisfaction Index (ACSI)}

Hasil perhitungan nilai ACSI taksi Bandar Udara Juanda Surabaya disajikan pada tabel berikut (Tabel 6).

Tabel 5.

Nilai ACSI

\begin{tabular}{|c|c|c|c|c|}
\hline Variabel & Indikator & Expentancy & Kinerja & Kepuasan \\
\hline \multirow{6}{*}{ Safety } & S1 & 6,71 & 5,71 & 5,76 \\
\hline & S2 & 6,69 & 5,68 & 5,59 \\
\hline & $\mathrm{C} 1$ & 6,21 & 4,87 & 4,79 \\
\hline & $\mathrm{C} 2$ & 6,35 & 4,91 & 4,82 \\
\hline & $\mathrm{C} 3$ & 6,32 & 4,97 & 4,91 \\
\hline & $\mathrm{C} 4$ & 6,02 & 5,08 & 5,10 \\
\hline \multirow{7}{*}{ Comfort } & $\mathrm{C} 5$ & 6,21 & 4,92 & 4,83 \\
\hline & C6 & 6,25 & 3,97 & 3,73 \\
\hline & $\mathrm{C} 7$ & 6,40 & 4,90 & 4,77 \\
\hline & $\mathrm{C} 8$ & 6,10 & 4,64 & 4,48 \\
\hline & C9 & 6,23 & 5,00 & 4,96 \\
\hline & $\mathrm{C} 10$ & 6,13 & 4,86 & 4,81 \\
\hline & A1 & 6,45 & 5,11 & 5,54 \\
\hline \multirow{3}{*}{ Accessibility } & $\mathrm{A} 2$ & 6,29 & 4,84 & 4,93 \\
\hline & A3 & 6,54 & 3,60 & 3,32 \\
\hline & A4 & 6,24 & 5,02 & 5,06 \\
\hline \multirow{3}{*}{$\begin{array}{c}\text { Timely } \\
\text { Performances }\end{array}$} & $\mathrm{T} 1$ & 6,21 & 5,19 & 5,17 \\
\hline & $\mathrm{T} 2$ & 6,07 & 4,89 & 4,92 \\
\hline & $\mathrm{T} 3$ & 6,24 & 5,29 & 5,38 \\
\hline Rata-Rata & \multicolumn{2}{|c|}{6,30} & 4,92 & 4,89 \\
\hline
\end{tabular}

Berdasarkan hasil perhitungan ACSI diatas maka didapatkan nilai ACSI sebesar 48,32 persen. Nilai 48,32 persen berada pada rentang 41-60 persen yang dapat diinterpretrasikan bahwa pengguna taksi Bandar Udara Juanda Surabaya merasa cukup puas terhadap layanan taksi resmi Bandar Udara Juanda Surabaya. Nilai indeks kepuasan tersebut kurang maksimal karena harapan dari pengguna taksi Bandar Udara Juanda Surabaya belum terpenuhi secara menyeluruh melihat hasil rata-rata tertimbang dari kinerja yaitu 4,92 dan kepuasan yaitu 4,89 yang masih berada dibawah hasil rata-rata tertimbang expentancy (harapan) yaitu 6,30 (Tabel 6).

Kepuasan penumpang yang tergolong rendah membutuhkan perhatian yang serius dari operator taksi resmi Bandar Udara Juanda Surabaya dengan menitikberatkan kepentingan konsumen. Beberapa kasus yang menimpa konsumen dimana pengguna taksi resmi Bandar Udara Juanda Surabaya sering menjadi korban, baik karena kurang terjangkaunya tarif taksi dan kepadatan terminal kedatangan sebagai lokasi penawaran jasa merupakan atribut dengan nilai kepuasan terendah. Kondisi saat ini adalah kebanyakan taksi resmi Bandar Udara Juanda Surabaya menerapkan pengenaan tarif berdasarkan zona dibandingkan argo meter sehingga menjadi pemicu tarif yang dikenakan kepada penumpang tergolong tinggi dan membuat pengemudi dengan segan langsung mematok harga tinggi untuk zona tertentu kepada penumpang.

Strategi penawaran jasa taksi kepada pengunjung Bandar Udara Juanda Surabaya di terminal kedatangan dengan mendirikan counter-counter taksi juga dirasa merupakan hal yang kurang tepat. Mayoritas sales dari masing-masing counter taksi menawarkan jasa taksi dengan cara meneriaki atau bahkan mengikuti konsumen yang pada akhirnya akan membuat merasa tidak nyaman, risih, atau bahkan akhirnya merasa secara terpaksa untuk mengiyakan penawaran jasa yang diberikan oleh para sales. Keterbatasan penyedia jasa taksi di Bandar Udara Juanda Surabaya juga dirasa dapat menjadi pemicu mengapa konsumen merasa secara keseluruhan kurang merasa puas atas layanan taksi resmi Bandar Udara Juanda Surabaya. Terbatasnya pilihan jasa taksi membuat konsumen merasa terpaksa untuk menggunakan taksi yang dipilih dan berakibat pada pengalaman yang diperoleh menjadi kurang menyenangkan. Oleh karena itu, semakin banyak taksi yang beroperasi maka semakin tinggi jaminan konsumen untuk memilih taksi yang diinginkan dan berakibat pada kepuasan maksimal di benak konsumen.

\section{D.Analisis Customer Loyalty Index (CLI)}

Langkah pertama yang harus dilakukan untuk menghitung CLI adalah menghitung mean dari masingmasing atribut loyalitas atau disebut dengan willing statement. Pada penelitian ini terdapat empat atribut loyalitas, dimana masing-masing willing statement atribut tersebut kemudian dibagi dengan nilai skala likert tertinggi yaitu 7 dan kemudian dikalikan dengan 100 persen. Kemudian dari perhitungan keempat atribut loyalitas tersebut akan dicari rata-ratanya untuk mendapatkan nilai Customer Loyalty Index (CLI) secara kesuluruhan. Berikut adalah hasil Customer Loyalty Index (CLI) taksi Bandar Udara Juanda Surabaya (Tabel 7).

\begin{tabular}{ccc}
\multicolumn{3}{c}{ Tabel 6. } \\
Nilai CLI \\
\hline \hline Indikator Loyalitas & Willing Statement & CLI (\%) \\
\hline L1 & 3,86 & 55,21 \\
L2 & 3,65 & 52,07 \\
L3 & 4,11 & 58,75 \\
L4 & 3,13 & 44,66 \\
& & 52,67 \\
\hline \hline
\end{tabular}

Nilai Customer Loyalty Index (CLI) taksi Bandar Udara Juanda Surabaya adalah sebesar 52,67 persen (Tabel 5). Nilai 52,67 persen berada pada rentang 51 hingga 70 persen yang dapat diinterpretrasikan bahwa pengguna taksi Bandar Udara Juanda Surabaya cukup loyal terhadap layanan taksi resmi Bandar Udara Juanda Surabaya. Walaupun secara keseluruhan penumpang taksi resmi Bandar Udara Juanda Surabaya merasa cukup loyal, namun mereka cenderung merasa kurang setuju menyampaikan hal-hal positif mengenai layanan tersebut kepada orang lain dan tidak setuju untuk menggunakan layanan tersebut secara terus menerus. Kecenderungan tersebut disebabkan oleh kinerja Perusahaan yang masih dibawah ekspektasi (harapan) yang mereka miliki.

Kondisi fisik maupun peforma pengemudi mampu menjadi alasan mengapa mereka merasa kurang setuju untuk menyampaikan hal-hal positif terkait layanan taksi resmi Bandar Udara Juanda Surabaya. Kondisi fisik kendaraan taksi resmi Bandar Udara Juanda terutama jenis taksi prima juanda (Kokapura dan Primkopal) menunjukkan kondisi kurang baik melihat usia kendaraan yang sudah tua namun tetap digunakan untuk beroperasi dan jenis kendaraan yang masih berupa sedan dan hanya bisa menampung sedikit penumpang. Selain itu, performa pengemudi yang kurang mendukung dilihat dari segi usia pengemudi dimana mayoritas dari mereka sudah berusia lanjut. Penampilan pengemudi yang tidak memenuhi standar seperti tidak berpakaian rapi dan bersih serta sikap pengemudi yang kurang baik dan ramah kepada 
penumpang juga dapat menjadi alasan mengapa mayoritas penumpang merasa kurang setuju untuk menyampaikan hal-hal positif terkait layanan. Begitu pula dengan kecenderungan mereka untuk tidak menggunakan layanan secara terus menerus dirasa karena kemampuan pesaing yang dapat memberikan tarif layanan jauh lebih terjangkau dengan promo-promo menarik yang diberikan. Kondisi saat ini mencerminkan bahwa tarif taksi resmi Bandar Udara Juanda Surabaya tergolong tinggi dibandingkan dengan kompetitor seperti transportasi berbasis aplikasi online. Tidak adanya promosi menarik seperti potongan harga atau program loyalitas menarik yang ditawarkan oleh Taksi resmi Bandar Udara Juanda Surabaya kepada penumpang pada akhirnya tentu akan mampu membuat penumpang mudah beralih ke pesaing atau produk substitusi lainnya.

\section{E. Implikasi Manajerial}

Setelah dilakukan analisis, maka selanjutnya dilakukan perumusan implikasi manajerial yang tepat bagi pihk taksi resmi Bandar Udara Juanda Surabaya dan PT Angkasa Pura I (Persero) untuk meningkatkan kepuasan dan loyalitas konsumen.

1. Implikasi Manajerial American Customer Satisfaction Index (ACSI)

Pengguna taksi Bandar Udara Juanda Surabaya saat ini merasa cukup puas terhadap pelayanan yang diberikan oleh operator taksi resmi Bandar Udara Juanda Surabaya. Akan tetapi di sisi lain diketahui bahwa harapan dari pengguna taksi Bandar Udara Juanda Surabaya belum terpenuhi secara sepenuhnya melihat hasil rata-rata tertimbang keseluruhan dari kinerja dan kepuasan yang dirasakan masih berada dibawah hasil rata-rata tertimbang harapan yang penumpang miliki. Pihak taksi resmi Bandar Udara Juanda Surabaya perlu meningkatkan kinerja perusahaan sesuai dengan yang diharapkan oleh penumpang, sehingga mampu memenuhi atau bahkan melampaui harapan yang penumpang miliki dan pada akhirnya mampu menciptakan kepuasan penumpang secara maksimal.

Berdasarkan saran dari responden penelitian, mayoritas responden merasa bahwa tarif yang ditetapkan oleh operator taksi resmi Bandar Udara Juanda Surabaya jauh lebih tinggi dibandingkan dengan transportasi berbasis aplikasi online. Mereka merasa bahwa banyak pengemudi yang menetapkan tarif seenaknya kepada penumpang, terutama melihat kondisi lebih banyak taksi yang beroperasi di Bandar Udara Juanda Surabaya menetapkan tarif berdasarkan zona dibandingkan argo meter. Selain itu, mayoritas responden merasa bahwa penawaran layanan taksi kepada pengunjung Bandar Udara Juanda Surabaya saat ini kurang tepat melihat tingkat kepadatan terminal kedatangan yang tinggi. Para sales masing-masing jenis taksi sangat agresif dalam menawarkan jasa seperti meneriaki hingga mengikuti pengunjung Bandar Udara Juanda Surabaya, sehingga membuat mereka tidak nyaman. Oleh karena hal tersebut, disarankan untuk operator taksi resmi Bandar Udara Juanda Surabaya mengubah sistem penetapan tarif taksi berdasarkan menjadi argo meter dan memberikan promosi berupa potongan harga yang dapat membuat penumpang merasa tarif yang dikenakan lebih terjangkau.

Cara penawaran jasa taksi kepada pengunjung Bandar Udara Juanda Surabaya dari direct selling juga dapat diubah secara perlahan dengan memanfaatkan media online yaitu website dan taxi counter. PT Angkasa Pura I (Persero) dapat meniadakan counter-counter taksi yang berdiri sendiri dan kemudian mendirikan taxi counter terpusat sebagai pusat informasi layanan taksi dengan operator yang handal dan meningkatkan jumlah mesin tiket taksi melihat saat ini hanya terdapat 4 mesin tiket taksi di terminal 1 Bandar Udara Juanda Surabaya serta menempatkannya di satu lokasi dengan taxi counter terpusat. Kondisi saat ini menunjukkan bahwa walaupun sebelumnya pengunjung Bandar Udara Juanda Surabaya sudah memiliki tiket taksi namun mereka harus antre kembali didekat jalur utama untuk mendapatkan taksi, oleh karena itu PT Angkasa Pura I (Persero) perlu memperbaharui struk pemesanan taksi dengan mencantumkan plat nomor taksi untuk menghindari adanya antrian.

Dengan memerbaiki dan meningkatkan kualitas layanan yang dimiliki saat ini serta melakukan berbagai program pemasaran yang inovatif dan menarik tentu akan mampu meningkatkan kepuasan penumpang sehingga terhindar dari sikap penumpang akan beralih ke penyedia jasa lainnya. Setelah meningkatkan kualitas layanannya, hal yang perlu dilakukan oleh pihak taksi resmi Bandar Udara Juanda Surabaya adalah membentuk tim khusus untuk memantau kepuasan pelanggan secara berkala agar dapat mengetahui perkembangan kepuasan pelanggannya sehingga pada akhirnya akan mempermudah pengambilan keputusan terkait program pemasaran yang akan dilakukan nantinya.

2. Implikasi Manjerial Customer Loyalty Index (CLI)

Konsumen merasa cukup loyal terhadap layanan taksi resmi Bandar Udara Juanda Surabaya. Hal tersebut merupakan pencapaian kurang maksimal karena walaupun secara keseluruhan penumpang taksi resmi Bandar Udara Juanda Surabaya merasa cukup loyal, namun mereka cenderung merasa kurang setuju menyampaikan hal-hal positif mengenai layanan tersebut kepada orang lain dan tidak setuju untuk menggunakan layanan tersebut secara terus menerus. Kecenderungan penumpang tersebut dapat diubah menjadi lebih baik dengan meningkatkan kualitas layanan yang mereka masih anggap tidak memenuhi harapannya dan kurang memuaskan.

Pihak taksi resmi Bandar Udara Juanda Surabaya juga perlu meningkatkan efektifitas program loyalitas yang dimiliki dan merumuskan program-program loyalitas pelanggan yang inovatif dan menarik mereka untuk mau menggunakan taksi resmi Bandar Udara Juanda Surabaya. Beberapa program loyalitas yang disarankan adalah yang pertama program poin, yaitu membuat inovasi program loyalitas pelanggan seperti penawaran member card kepada pengguna taksi yang dapat memberikan keuntungan berupa perolehan poin untuk setiap perjalanan yang dapat ditukar untuk potongan tarif penggunaan taksi selanjutnya. Kedua, program tier yaitu memberikan reward berdasarkan frekuensi penumpang menggunakan taksi resmi Bandar Udara Juanda Surabaya melalui pemesanan online yang telah dilakukan. Ketiga, program kemitraan yaitu memberikan promo melalui kerjasama dengan maskapai penerbangan. Misal: Taksi resmi Bandar Udara Juanda Surabaya bekerjasama dengan Lion Air. Lion Air menawarkan promo free ride menggunakan taksi untuk penumpang pesawat kelas bisnis. Program kemitraan juga dapat dilakukan dengan memberikan promo melalui kerjasama dengan PT Angkasa Pura I (Persero) beserta mitranya. Misal: Taksi resmi Bandar Udara Juanda Surabaya bekerjasama dengan blue sky lounge. Blue sky lounge menawarkan free ride mennggunakan taksi untuk pelanggan kelas VIP. 


\section{V.SIMPULAN DAN SARAN}

\section{A. Simpulan}

Berdasarkan analisis yang telah dilakukan pada bab sebelumnya, berikut adalah beberapa hal yang dapat disimpulkan pada penelitian ini.

1. Persepsi memainkan peran penting dalam menentukan kualitas layanan dan menciptakan kepuasan pelanggan secara keseluruhan. Semakin tinggi persepsi yang dimiliki oleh pelanggan terhadap layanan yang digunakan, maka semakin tinggi pula kepuasan yang dirasakan oleh pelanggan. Pentingnya persepsi sebagai pembentuk kepuasan konsumen secara maksimal membuat perusahaan taksi resmi Bandar Udara Juanda Surabaya perlu menciptakan kualitas kinerja yang mampu membentuk persepsi positif dibenak konsumen.

2. Pengguna taksi resmi Bandar Udara Juanda Surabaya menunjukkan bahwa mereka merasa cukup puas dan cukup loyal atas layanan taksi resmi Bandar Udara Juanda Surabaya. Walaupun begitu ternyata mereka cenderung merasa kurang setuju untuk menyampaikan hal-hal positif mengenai layanan tersebut kepada orang lain dan tidak setuju menggunakan layanan tersebut secara terus menerus. Kecenderungan penumpang tersebut dapat diubah menjadi lebih baik dengan meningkatkan kualitas layanan yang mereka masih anggap tidak memenuhi harapannya dan kurang memuaskan. Beberapa atribut layanan perlu ditinkatkan kinerjanya antara lain terminal kedatangan yang kurang cocok digunakan sebagai lokasi penawaran layanan, ketidakterjangkauan tarif layanan, sikap pengemudi masih buruk, pengalaman menggunakan layanan kurang menyenangkan dan kemudahan memeroleh informasi biaya atas layanan. Atribut-atribut tersebut perlu diperhatikan dan diprioritaskan terlebih dahulu oleh perusahaan untuk diperbaiki sehingga persepsi pengguna taksi Bandar Udara Juanda Surabaya menjadi semakin meningkat atau bahkan melampaui ekspektasi yang mereka miliki. Selain itu, operator taksi resmi bandar Udara Juanda Surabaya dan PT Angkasa Pura I (Persero) dapat saling bekerjasama untuk menciptakan berbagai program loyalitas yang inovatif dan menarik.

\section{B. Keterbatasan dan Saran penelitian}

Terdapat beberapa keterbatasan pada penelitian ini. Pertama, Penelitian ini terbatas pada pengunjung dan taksi resmi Bandar Udara Juanda Surabaya. Keadaan tersebut mempersulit peneliti untuk mendapatkan responden dalam jumlah banyak karena kondisi Bandar Udara Juanda Surabaya yang begitu padat dan hampir seluruh pengunjungnya memiliki mobilitas tinggi. Selain itu, keadaan tersebut juga membuat responden penelitian cenderung menjawab pertanyaan kuesioner dengan waktu yang relatif singkat. Kedua, hasil implikasi manajerial penelitian ini hanya dapat diterapkan di Bandar Udara Juanda Surabaya. Hal tersebut disebabkan oleh setiap wilayah atau lokasi memiliki karakter berbeda-beda sehingga strategi yang dibutuhkan setiap wilayah juga berbeda-beda. Ketiga, pemahaman responden terkait taksi yang digunakan di Bandar Udara Juanda Surabaya masih rendah sehingga mereka menganggap semua taksi resmi Bandar Udara Juanda Surabaya memiliki kualitas layanan yang sama. Hal tersebut menyebabkan apabila salah satu jenis taksi resmi Bandar Udara Juanda Surabaya memiliki kualitas layanan yang buruk, maka akan memengaruhi jenis taksi lainnya. Keempat, implikasi manajerial yang disarankan terbentuk hanya berdasarkan sudut pandang pengguna taksi resmi Bandar Udara Juanda Surabaya dan penulis.

Berdasarkan keterbatasan penelitian tersebut, saran untuk penelitian selanjutnya adalah pengumpulan data lebih difokuskan melalui penyebaran kuesioner kepada pengunjung Bandar Udara Juanda Surabaya yang sedang menunggu pesawat. Kedua, sampel penelitian dapat difokuskan kepada seorang commuter (seseorang yang bepergian ke suatu kota untuk bekerja dan kembali ke kota tempat tinggalnya setiap hari) yang bersedia kembali ke Kota Surabaya lagi dan pernah menggunakan taksi Bandar Udara Juanda Surabaya dalam kurun waktu tiga bulan terakhir. Hal tersebut perlu dilakukan agar mempermudah proses pengambilan data dan mendapat tingkat akurasi jawaban responden lebih tinggi. Ketiga, fokus kepada hanya satu jenis taksi resmi Bandar Udara Juanda Surabaya untuk memberikan tingkat akurasi jawaban dari responden yang tinggi terhadap pertanyaan kuesioner yang diajukan Keempat, hasil penelitian ini dapat digunakan sebagai acuan penelitian selanjutnya untuk menentukan strategi taksi konvensional di wilayah lain. Akan tetapi perlu dilakukan analisis lebih jauh lagi terkait kondisi wilayah lain tersebut karena karakter wilayah yang berbeda membutuhkan strategi yang berbeda pula. Kelima, Implikasi manajerial yang disarankan oleh penelitian selanjutnya diharapkan mampu menggabungkan seluruh perspektif baik dari pengguna taksi resmi Bandar Udara Juanda Surabaya, pengemudi taksi, dan perusahaan sehingga mampu menghasilkan hasil peenlitian yang lebih baik.

\section{DAFTAR PUSTAKA}

[1] M. Feeney, PolicyAnalysis - Is Ridesharing safe?, vol. 767, no. 767. 2015.

[2] C. Gronroos, "Service Management: A Management Focus for Service Competition,” Int. J. Serv. Ind. Manag., vol. 1, no. 1, pp. 614, 1990.

[3] M. F. Aryanto, "Pengaruh Education Service Quality terhadap Kepuasan dan Loyalitas Pelanggan Canadian English Course," Institut Teknologi Sepuluh Nopember, 2016.

[4] A. Parasuraman, V. A. Zeithaml, and L. L. Berry, "A conceptual model of service quality and its implications for future research | Adamu Galadima Dagona - Academia.edu,” J. Mark., vol. 49, no. 4, pp. 41-50, 1985.

[5] M. Kotler, P., Keller, K. L., Brady, Marketing management, vol. 13 no. 3. 2001 .

[6] Marketeers Editor, "Lima Elemen Service Quality,” Marketeers, 2013. [Online]. Available: http://marketeers.com/lima-elemenservice-quality/.

[7] S. Deb and M. Ali Ahmed, "Determining the service quality of the city bus service based on users' perceptions and expectations," Travel Behav. Soc., vol. 12, pp. 1-10, 2018

[8] P. F. Anderson and T. M. Chambers, "A Reward/Measurement Model of Organizational Buying Behavior,” J. Mark., vol. 49, no. 2, pp. 7-23, 1985.

[9] L. Parasuraman, A., Zeithaml, V., Berry, "SERVQUAL: A MultipleItem Scale for Measuring Consumer Perceptions of Service Quality," Jorunal Retail., vol. 64, no. 64, pp. 12-40, 1988.

[10] C. Lovelock and J. Wirtz, Service marketing: People, technology, and strategy, 7th ed., vol. null. New Jersey: Prentice Hall, 2004.

[11] L. Eboli and G. Mazzulla, "A methodology for evaluating transit service quality based on subjective and objective measures from the passenger's point of view," Transp. Policy, vol. 18, no. 1, pp. 172$181,2011$.

[12] L. Dell'Olio, A. Ibeas, and P. Cecin, "The quality of service desired by public transport users," Transp. Policy, vol. 18, no. 1, pp. 217$227,2011$.

[13] T. Litman, "Evaluating accessibility for transport planning evaluating accessibility for transportation planning," Victoria Transp. Policy Inst., no. January 2008, p. 49, 2017.

[14] N. Van Oort, "Service Reliability and Urban Public Transport Design Service Reliability and," p. 290, 2011.

[15] T. Firew, "Analysis of service reliability of public transportation in the Helsinki capital region: The case of bus line 550," 2016.

[16] R. L. Oliver, "Whence Consumer Loyalty?," J. Mark., vol. 63, no. 
1, p. 33, 1999.

[17] W. G. Zikmund, B. J. Babin, J. C. Carr, and M. Griffin, Business Research Methods, 11th ed. Singapura: McGraw-Hill International, 2013

[18] Verint Systems, "ACSI (American Customer Satisfaction Index) Score \&amp; Its Calculation," Blog, 2016. [Online]. Available: http://blog.verint.com/acsi-american-customer-satisfaction-indexscore-its-calculation.

[19] B. M. Wibawa, Strategi Pemasaran dalam Perspektif Perilaku Konsumen. Bogor: PT Penerbit IPB Press, 2018
[20] D. Ihshani, "Analisis kepuasan konsumen terhadap atribut wisata cangkuang Garut, Jawa Barat," Institut Pertanian Bogor, 2005.

[21] A. S. Wibowo, H. K. Suwarsinah, and L. N. Yuliati, "The Effects of PVTI's Corporate Image and Service Quality on Satisfaction and Loyalty of The KSO SCISI Customers," Indones. J. Bus. Entrep., vol. 4, no. 1, pp. 75-87, 2018.

[22] S. N. Husin and B. M. Wibawa, "Identifikasi Perilaku Konsumen Online Ride Sharing : Studi Kasus Go-Jek dan Grab," J. Sains dan Seni ITS, pp. 1-4. 
